\title{
Effects on lactating dairy cows of oscillating dietary concentrations of unsaturated and total long-chain fatty acids
}

\author{
W. P. Weiss, ${ }^{*} \dagger^{1}$ D. E. Shoemaker, $\dagger$ L. R. McBeth, ${ }^{*}$ and N. R. St-Pierre ${ }^{*} \dagger$ \\ *Department of Animal Sciences, Ohio Agricultural Research and Development Center, The Ohio State University, Wooster 44691 \\ †Ohio State University Extension, Wooster 44691
}

\begin{abstract}
The nutrient composition of diets can vary from batch to batch because of variation in the nutrient composition of ingredients. The concentration of fat in distillers grains can be highly variable and, coupled with a high dietary inclusion rate, can result in substantial variation in the fat concentration of the total diet. Our hypothesis was that variation in dietary fat concentrations over short periods would have negative effects on production measures of dairy cattle. Twenty-four Holstein cows were used in 8 truncated Latin squares (3 cows $\times 2$ periods). Periods were $16 \mathrm{~d}$ long, with a 12 -d washout period separating the 2 periods. The 3 treatments were 1) control, 2) moderate variation, and 3) high variation. The control treatment was a consistent diet over the $16 \mathrm{~d}$ and contained $5.8 \%$ (dry basis) total long-chain fatty acids (LCFA), $23.7 \%$ distillers grains, and $1.1 \%$ of dry matter as corn oil. The average concentration of LCFA over the 16-d period for the moderate variation and high variation treatments was also $5.9 \%$, but concentrations of LCFA varied over time by the addition or removal of corn oil. The moderate variation treatment had a 4-d phase of 5.4\% LCFA, followed by a 4 -d phase with $6.4 \%$ LCFA to complete the cycle, and then the cycle was repeated. The high variation treatment followed the same cycle pattern, but concentration of LCFA was either 4.8 or $7.0 \%$. Over the 16 $\mathrm{d}$, dry matter intake and milk yield were significantly decreased by the high variation treatment (intake = $21.7,21.8$, and $20.7 \mathrm{~kg} / \mathrm{d}$; milk $=36.4,37.6$, and 35.4 $\mathrm{kg} / \mathrm{d}$ for the control, moderate variation, and high variation treatments). The effect of variation appeared to be cumulative; differences were not significant in the first 8-d cycle but were in the second 8-d cycle. Milk fat concentration was low $(2.4 \%)$ and was not affected by treatment or cycle $\times$ treatment. The concentration of trans-10 C18:1 in milk fat was very high (4.2\% of total milk fatty acids) but was not affected by treat-
\end{abstract}

Received June 13, 2012.

Accepted September 8, 2012.

${ }^{1}$ Corresponding author: weiss.6@osu.edu ment. However, cows on the high variation treatment had higher concentrations of trans-10, cis-12 C18:2 in milk fat $(0.036,0.042$, and $0.047 \%$ of milk fatty acids for the control, moderate variation, and high variation treatments). Overall, an extreme short-term fluctuation in dietary fat concentration was needed before negative effects were observed.

Key words: distillers grains, milk fatty acid, supplemental fat, variation

\section{INTRODUCTION}

All feedstuffs vary in their nutrient composition because of plant genetics, growing conditions, harvest and storing systems, and manufacturing differences, among others. The composition of both concentrates and forages can change significantly over short periods of time (Weiss et al., 2012), and that could cause substantial short-term changes in TMR composition. The effects of short-term changes in the nutrient composition of diets have not been studied, with the exception of oscillating concentrations of dietary CP (i.e., a short period of high CP followed by a short period of low CP repeated in a cyclic pattern) fed to beef cattle and sheep (Cole, 1999; Ludden et al., 2002; Cole et al., 2003). In general, growth and nutrient utilization measures of animals fed the oscillating protein diets were equal or slightly improved compared with animals fed a constant $\mathrm{CP}$ diet that was approximately equal to the average $\mathrm{CP}$ of the oscillating treatment.

Because of the burgeoning ethanol industry in the United States, distillers grains are becoming a common ingredient in dairy diets. However, numerous surveys have shown that the nutrient composition of distillers grains can be quite variable, depending on the source and other factors (Belyea et al., 1989; DePeters et al., 2000; Spiehs et al., 2002; Buckner et al., 2011). Within a survey, average fat concentrations among distilleries have ranged by as much as 4 percentage units, and within-distillery coefficients of variation have been as high as 12\% (Spiehs et al., 2002). A large national feedtesting laboratory reported an average fat concentration in dried distillers grains (4,819 samples) of $12.6 \%$ 
with a standard deviation of 3.2 (Dairy One, 2011). The majority of fat in dried distillers grains is unsaturated (Abdelqader et al., 2009), and excess unsaturated FA can have negative effects on dairy cows (Harvatine and Allen, 2006). We hypothesized that diets with short-term variation (days) in the concentration of unsaturated FA would negatively affect cows even though, across a few weeks, the average concentration of unsaturated FA would be equal to a diet with a consistent day-to-day concentration of unsaturated FA.

\section{MATERIALS AND METHODS}

\section{Cows, Diets, and Experimental Design}

Twenty-four Holstein cows (average DIM = 140 d; $\mathrm{SD}=22 \mathrm{~d}$ ) were blocked into groups of 3 by parity ( 3 blocks of first-parity cows and 5 blocks of multiparous cows) and milk production, and each block was used in 1 of 8 truncated ( 3 cows $\times 2$ periods) Latin squares. The first 4 squares were conducted concurrently, and when they were completed, the next 4 squares were conducted (the 2 groups of squares are designated as a group in the statistical model). Periods were $16 \mathrm{~d}$ long, and a washout period of $12 \mathrm{~d}$ separated the 2 periods. All cows were moved into the tie-stall barn and fed a preliminary diet for $8 \mathrm{~d}$ (this diet was also fed during the washout period between the 2 treatment periods). The preliminary diet (DM basis) was $38 \%$ corn silage, $20 \%$ alfalfa silage, $17 \%$ corn gluten feed, $14.6 \%$ ground corn grain, $7.4 \%$ soybean meal, $2.7 \%$ mineral-vitamin premix, and $0.3 \%$ animal-vegetable blend fat and contained 3.0\% long-chain FA (LCFA), 30\% NDF, and $17 \%$ CP (assayed values, methods described below). After the preliminary period and washout period, cows were abruptly changed to 1 of 3 treatment regimens (Figure 1). The control treatment was a consistent dayto-day diet (Table 1) that was formulated to contain $5.9 \%$ LCFA. Cows on the second treatment (moderate variation treatment) were fed a diet with $6.4 \%$ LCFA for a 4 -d phase, then abruptly changed to a diet with $5.4 \%$ LCFA for a 4 -d phase, then $6.4 \%$ for $4 \mathrm{~d}$, and then $5.4 \%$ for $4 \mathrm{~d}$ (i.e., two 4 -d phases within two 8-d cycles). Cows on the third treatment (high variation treatment) followed the same schedule as cows on the moderate variation treatment except that the diet contained either 7.0 or $4.8 \%$ LCFA (Figure 1). Over the 16-d period, the average concentrations of LCFA in the diets were the same for all treatments. Two concentrate mixes (one with no added corn oil and one with $4.1 \%$ added corn oil) were made at the feed mill, and daily TMR were made at the dairy center by using different ratios of those 2 concentrate mixes. Cows were housed in tie stalls, fed once daily for ad libitum consumption

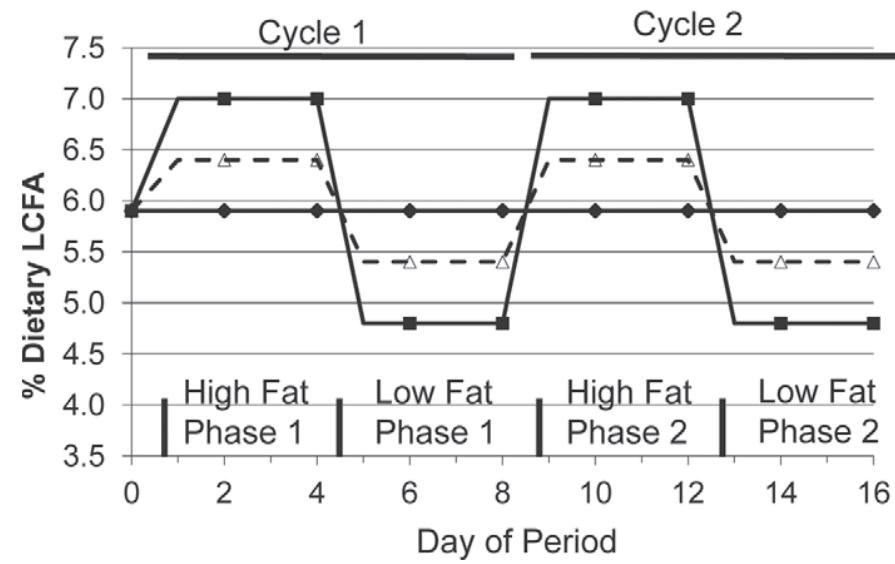

Figure 1. Treatment and milk sampling schedule. The control diet was $5.9 \%$ long-chain FA (LCFA) over the 16-d period (solid line, diamonds). The moderate variation treatment had diets with 6.4 or $5.4 \%$ LCFA fed in 4-d phases (dashed line, triangles). The high variation treatment had diets with 7.0 or $4.8 \%$ LCFA (solid line, squares). The days with a marker indicate when milk (morning and evening) was sampled. After this 16-d period was finished, cows were fed a preliminary diet for $12 \mathrm{~d}$ and then assigned to new treatments, and the schedule was repeated.

(amount of DM offered daily averaged $108 \%$ of DMI), and milked twice daily. Cows were weighed approximately $2 \mathrm{~h}$ after feeding on the first and last day of each period, and average BW were $589 \pm 40 \mathrm{~kg}$ for first-parity cows and $652 \pm 45 \mathrm{~kg}$ for multiparous cows.

The control diet was formulated to mimic a diet with a $25 \%$ inclusion rate of distillers grains that contained $11.2 \%$ fat (mean fat concentration from 49 samples of distillers grains from across the United States compiled in March 2009; University of Minnesota, 2009). The standard deviation for fat concentration in that data set was $1.6 \%$. The moderate variation treatment represents the mean fat concentration for distillers grains \pm 1.2 standard deviation units (i.e., $75 \%$ of the population should be within $\pm 1.2 \mathrm{SD}$ units). The high variation treatment represents the mean fat concentration of distillers grains \pm 3 standard deviation units (i.e., $99 \%$ of the population). An infinite number of dietary treatment patterns are possible, but we chose to use 4-d phases to mimic a farm receiving a new shipment of distillers grains every $4 \mathrm{~d}$ (i.e., a 750-cow dairy farm feeding a diet with $25 \%$ distiller grains would require a 20-tonne load approximately every $4 \mathrm{~d}$ ). A consistent pattern of high, low, high, low fat concentration is unlikely to occur; however, this was chosen because it simplified the experimental protocol and because it represents a worst-case scenario (abrupt change from very low to very high fat concentrations). If this amount of variation does not influence cows, then it is unlikely that less (more realistic) variation would influence cows. 
Table 1. Ingredient composition of rations (\% of DM)

\begin{tabular}{|c|c|c|c|c|c|}
\hline \multirow[b]{2}{*}{ Ingredient } & \multirow[b]{2}{*}{ Control } & \multicolumn{2}{|c|}{ Moderate variation } & \multicolumn{2}{|c|}{ High variation } \\
\hline & & Low fat & High fat & Lowest fat & Highest fat \\
\hline Corn silage $^{1}$ & 42.0 & 42.0 & 42.0 & 42.0 & 42.0 \\
\hline Alfalfa silage $^{2}$ & 10.0 & 10.0 & 10.0 & 10.0 & 10.0 \\
\hline Corn grain, ground & 17.22 & 17.50 & 16.93 & 17.79 & 16.68 \\
\hline Soybean meal, $48 \%$ CP & 0.71 & 0.71 & 0.71 & 0.71 & 0.70 \\
\hline High-protein distillers grains ${ }^{3}$ & 13.17 & 17.56 & 8.78 & 21.96 & 4.4 \\
\hline Distillers grains $^{4}$ & 10.55 & 7.80 & 13.29 & 5.06 & 16.0 \\
\hline Corn gluten meal & 2.61 & 1.31 & 3.92 & 0 & 5.22 \\
\hline Corn oil & 1.11 & 0.56 & 1.67 & 0 & 2.22 \\
\hline Urea & 0.15 & 0.08 & 0.22 & 0 & 0.30 \\
\hline Trace mineral salt & 0.41 & 0.41 & 0.41 & 0.41 & 0.41 \\
\hline Limestone & 1.39 & 1.39 & 1.39 & 1.39 & 1.39 \\
\hline Magnesium oxide & 0.11 & 0.11 & 0.11 & 0.11 & 0.11 \\
\hline Trace nutrient premix ${ }^{5}$ & 0.57 & 0.57 & 0.57 & 0.57 & 0.57 \\
\hline \multicolumn{6}{|c|}{$\begin{array}{l}{ }^{1} \text { Corn silage averaged } 37.5 \% \mathrm{DM}, 38.6 \% \mathrm{NDF}, 36.6 \% \text { starch, } 6.5 \% \mathrm{CP} \text {, and } 3.0 \% \text { long-chain FA (LCFA). } \\
{ }^{2} \text { Alfalfa silage averaged } 41.8 \% \mathrm{DM}, 43.0 \% \mathrm{NDF}, 1.4 \% \text { starch, } 25.0 \% \mathrm{CP} \text {, and } 2.8 \% \text { LCFA. } \\
{ }^{3} \text { Dakota Gold HP Dried Distillers Grains (Poet Nutrition, Sioux Falls, SD). } \\
{ }^{4} \text { Dakota Gold BPX Dried Distillers Grains with Solubles (Poet Nutrition). } \\
{ }^{5} \text { The premix contained } 50 \mathrm{mg} \text { of Se (from sodium selenate), } 1,875 \mathrm{mg} \text { of } \mathrm{Cu} \text { (from copper sulfate), } 2,700 \mathrm{mg} \\
\text { of Zn (from zinc sulfate), } 564 \mathrm{kIU} \text { of vitamin A, } 186 \mathrm{kIU} \text { of vitamin D, } 4,140 \mathrm{IU} \text { of vitamin E, and } 125 \mathrm{mg} \text { of } \\
\text { biotin per kilogram. }\end{array}$} \\
\hline
\end{tabular}

\section{Sampling and Analyses}

Milk (morning and evening) was sampled at the start of the experiment when all cows were fed the preliminary diet and then sampled on the second and fourth day of each phase (Figure 1). Within each day, the morning and evening samples were composited based on milk yield. The morning and evening samples taken on the second day and fourth days were taken approximately 22 and $34 \mathrm{~h}$ and 70 and $82 \mathrm{~h}$ after the abrupt change in diets. The composited samples were assayed for milk fat, protein, lactose [B2000 Infrared Analyzer (combined Filters A and B were used); Bentley Instruments, Chaska, MN] and MUN (Skalar SAN Plus Segmented Flow Analyzer; Skalar Inc., Norcross, GA) by DHI Cooperative Inc. (Columbus, OH). Milk FA profile of the composited samples was determined by using a 2-step procedure for methylation (Jenkins, 2000), with separation by GLC using a CP-SIL88 capillary column $(100 \mathrm{~m} \times 0.25 \mathrm{~mm} \times 0.2 \mu \mathrm{m}$ film thickness; Varian Inc., Palo Alto, CA). Instrument conditions were an injector temperature of $250^{\circ} \mathrm{C}$, a flame-ionization detector temperature of $255^{\circ} \mathrm{C}$, hydrogen carrier gas at 0.8 $\mathrm{mL} / \mathrm{min}$, detector makeup gas $\left(\mathrm{N}_{2}\right)$ at $20 \mathrm{~mL} / \mathrm{min}$, and an injector split ratio of 75:1. The initial column temperature was $100^{\circ} \mathrm{C}$, programmed at $6^{\circ} \mathrm{C} / \mathrm{min}$ to $170^{\circ} \mathrm{C}$ for $50 \mathrm{~min}$, and then $8^{\circ} \mathrm{C} / \mathrm{min}$ to $220^{\circ} \mathrm{C}$ for $20 \mathrm{~min}$.

The 2 silages and 2 concentrate mixes were sampled weekly and composited by period $(\mathrm{n}=4$ for each feedstuff). Composited samples were ground (silage samples were lyophilized first) through a 1-mm screen (Wiley Mill; Arthur A. Thomas, Philadelphia, PA).
Ground samples were assayed for $\mathrm{DM}\left(100^{\circ} \mathrm{C}\right.$ oven for 24 h), NDF (Ankom ${ }^{200}$ Fiber Analyzer; Ankom Technology, Fairport, NY) with sodium sulfite and amylase (Sigma A3306; Sigma Diagnostics, St. Louis, MO), CP (Kjeldahl $\mathrm{N} \times 6.25$ ), ash (AOAC, 2000), starch (Weiss and Wyatt, 2000), and LCFA (Weiss and Wyatt, 2003). Orts were sampled from each cow on d 4 and 14 of each period and assayed for $\mathrm{DM}\left(100^{\circ} \mathrm{C}\right.$ oven overnight $)$ to calculate DMI.

\section{Statistical Analyses}

Data were analyzed as a mixed model using the MIXED procedure (SAS Institute, 2009). The model included the fixed effects of group $(1 \mathrm{df})$, period within group ( $2 \mathrm{df})$, treatments ( $2 \mathrm{df})$, cycle $(1 \mathrm{df})$, and days of the cycle $(3 \mathrm{df})$, plus all relevant 2-way and 3-way interaction terms, and the random effect of cow within group. The covariance of errors for all measurements made on an animal within the same period (i.e., 8 measurement days) was modeled using the heterogeneous, first-order autoregressive, $\mathrm{ARH}(1)$, structure. Denominator degrees of freedom for all tests were adjusted using the Kenward-Rogers option. Whenever significant $(P<0.10)$, the interaction of treatment $\times$ days of the cycle was decomposed into simple comparisons using the SLICE option of the LSMEANS statement of SAS.

\section{RESULTS AND DISCUSSION}

For simplicity, treatments are described only in terms of variation in fat concentrations; however, other nutri- 
Table 2. Nutrient composition of diets (\% of DM except for Mcal $/ \mathrm{kg}$ of $\mathrm{DM}$ for $\mathrm{NE}_{\mathrm{L}}$ )

\begin{tabular}{|c|c|c|c|c|c|}
\hline \multirow[b]{2}{*}{ Nutrient } & \multirow[b]{2}{*}{ Control } & \multicolumn{2}{|c|}{ Moderate variation } & \multicolumn{2}{|c|}{ High variation } \\
\hline & & Low fat & High fat & Lowest fat & Highest fat \\
\hline $\mathrm{DM}$ & 63.0 & 63.0 & 63.3 & 63.0 & 63.0 \\
\hline $\mathrm{LCFA}^{1}$ & 5.81 & 5.24 & 6.39 & 4.67 & 6.96 \\
\hline C16:0 & 0.75 & 0.69 & 0.80 & 0.64 & 0.85 \\
\hline C18:0 & 0.12 & 0.11 & 0.13 & 0.10 & 0.13 \\
\hline C18:1 cis-9 & 1.21 & 1.05 & 1.37 & 0.88 & 1.54 \\
\hline $\mathrm{C} 18: 2$ & 2.89 & 2.56 & 3.22 & 2.23 & 3.55 \\
\hline C18:3 & 0.18 & 0.17 & 0.18 & 0.16 & 0.19 \\
\hline Other and unidentified & 0.68 & 0.67 & 0.69 & 0.65 & 0.70 \\
\hline Total unsaturated & 4.28 & 3.78 & 4.77 & 3.27 & 5.28 \\
\hline Ash & 5.5 & 5.4 & 5.6 & 5.3 & 5.7 \\
\hline NFC & 40.7 & 40.9 & 40.4 & 41.2 & 40.1 \\
\hline NDF & 30.3 & 30.7 & 29.9 & 31.1 & 29.5 \\
\hline Starch & 26.8 & 27.0 & 26.7 & 27.2 & 26.5 \\
\hline $\mathrm{CP}$ & 16.7 & 16.7 & 16.7 & 16.7 & 16.7 \\
\hline $\mathrm{RDP}^{2}$ & 9.9 & 10.1 & 9.8 & 10.2 & 9.8 \\
\hline $\mathrm{RUP}^{2}$ & 7.7 & 7.6 & 7.8 & 7.4 & 7.8 \\
\hline $\mathrm{NE}_{\mathrm{L}}^{2}$ & 1.69 & 1.67 & 1.71 & 1.65 & 1.73 \\
\hline $\mathrm{Ca}$ & 0.81 & 0.86 & 0.76 & 0.91 & 0.77 \\
\hline $\mathrm{Mg}$ & 0.20 & 0.20 & 0.21 & 0.19 & 0.21 \\
\hline $\mathrm{P}$ & 0.40 & 0.39 & 0.40 & 0.38 & 0.40 \\
\hline $\mathrm{K}$ & 1.07 & 1.06 & 1.07 & 1.06 & 1.07 \\
\hline
\end{tabular}

${ }^{1}$ Long-chain FA; number of carbons:number of double bonds.

${ }^{2}$ Calculated according to the NRC (2001) model using treatment average DMI and assayed nutrients, except for protein fractions and protein digestion rate.

ents and ingredients also had to vary in concert with changes in fat concentrations (Tables 1 and 2). The assayed mean concentrations of LCFA in the 5 test diets (Table 2) were very close to the targeted values of 5.9, $5.4,6.4,4.8$, and $7.0 \%$ (control, moderate variationlow and high fat, and high variation-low and high fat, respectively). The calculated $95 \%$ confidence intervals for LCFA for the 5 diets (same order) were 5.6-6.1, 5.0-5.5, 6.1-6.6, 4.4-4.9, and 6.7-7.2.

The objective of this experiment was not to evaluate transient responses to transient changes in the diet but rather to determine whether average responses (over time) differed when the dietary concentration of LCFA varied over time but on average were equal. The 16-d average DMI was lower $(P<0.08)$ for cows fed the high variation treatment compared with the other 2 treatments (Table 3). The time profile of DMI had a more dramatic effect of treatment (Figure 2) and illustrates the cycle $\times$ treatment interaction $(P<0.05)$. During the first cycle of high- and low-fat diets, treatment had no effect on DMI, but during the second cycle, cows on the high variation treatment had lower DMI than cows on the other 2 treatments $(P<0.03)$. Alternating between 5.4 and $6.4 \%$ dietary LCFA had no effect on DMI compared with a diet that consistently contained 5.9\% LCFA; however, alternating between 4.8 and $7.0 \%$ LCFA appeared to have a cumulative negative effect on DMI. Feeding diets for $21 \mathrm{~d}$ with increasing concentrations of unsaturated LCFA (3.9 to $4.9 \%)$ linearly decreased DMI and milk yield in dairy cows (Harvatine and Allen, 2006). However, we observed no short-term (between phases of high- and low-fat concentrations) effects on DMI to large changes in unsaturated LCFA concentrations ( 3.3 vs. $5.3 \%$ for the high variation treatment). Milk yield over the $16-\mathrm{d}$ period decreased when cows were fed the high variation treatment, but it was only statistically lower $(P<0.05)$ than the moderate variation group (Table 4 and Figure 2). A treatment $\times$ cycle interaction $(P<0.08)$ was observed in that milk yields did not differ among treatments in the first cycle, but cows fed the high variation treatment had lower milk yields than cows in the moderate $(P<0.02)$ and control $(P<0.10)$ treatments during the second cycle. The lower milk yield was likely in response to lower DMI because feed efficiency was not affected by treatment (Table 4) and was constant over time (data not shown).

Milk protein, lactose, and MUN concentrations were not affected by treatment, but yields of lactose and protein followed the same treatment pattern as did milk yield, with cows on the high variation treatment producing less milk protein and lactose than cows on the moderate variation treatment (Table 4). Yields of milk protein and lactose were not affected by treatment in the first cycle, but yields decreased with the high variation treatment in the second cycle $(P<0.09$ and 0.02 for high vs. control and high vs. moderate variation for milk protein and $P<0.04$ and 0.01 , respectively, for 
Table 3. Effect of changing dietary fat concentrations on production measures

\begin{tabular}{lccccc}
\hline Measure & Control & $\begin{array}{c}\text { Moderate } \\
\text { variation }\end{array}$ & $\begin{array}{c}\text { High } \\
\text { variation }\end{array}$ & SEM & $P$-value \\
\hline DMI, ${ }^{1} \mathrm{~kg} / \mathrm{d}$ & $21.7^{\mathrm{a}}$ & $21.8^{\mathrm{a}}$ & $20.7^{\mathrm{b}}$ & 0.61 & $<0.08$ \\
Milk yield, $\mathrm{kg} / \mathrm{d}$ & $36.4^{\mathrm{ab}}$ & $37.6^{\mathrm{a}}$ & $35.4^{\mathrm{b}}$ & 0.94 & $<0.07$ \\
Milk/DMI, kg/kg & 1.71 & 1.73 & 1.73 & 0.04 & $<0.6$ \\
Milk fat, \% & 2.37 & 2.37 & 2.47 & 0.11 & $<0.6$ \\
Milk protein, \% & 2.97 & 2.94 & 2.95 & 0.04 & $<0.7$ \\
Milk lactose, \% & 4.80 & 4.83 & 4.80 & 0.035 & $<0.7$ \\
MUN, mg/dL & 16.3 & 16.2 & 15.8 & 0.47 & $<0.7$ \\
Milk fat, $\mathrm{kg} / \mathrm{d}$ & 0.85 & 0.87 & 0.88 & 0.035 & $<0.6$ \\
Milk protein, $\mathrm{kg} / \mathrm{d}$ & 1.08 & $1.11^{\mathrm{a}}$ & $1.04^{\mathrm{b}}$ & 0.029 & $<0.07$ \\
Milk lactose, $\mathrm{kg} / \mathrm{d}$ & 1.76 & $1.82^{\mathrm{a}}$ & $1.69^{\mathrm{b}}$ & 0.47 & $<0.01$ \\
\hline
\end{tabular}

$\overline{\mathrm{a}, \mathrm{b}}$ Means within a row with unlike superscripts differ by the stated $P$-value.

${ }^{1}$ A treatment $\times$ cycle interaction was observed for DMI $(P<0.05)$ and milk $(P<0.08)$.

lactose). Diets with supplemental fat often reduce milk protein concentration, but treatment average protein concentrations were normal and no cyclicity was observed as higher and lower fat diets were fed (data not shown). Average MUN concentrations were higher than
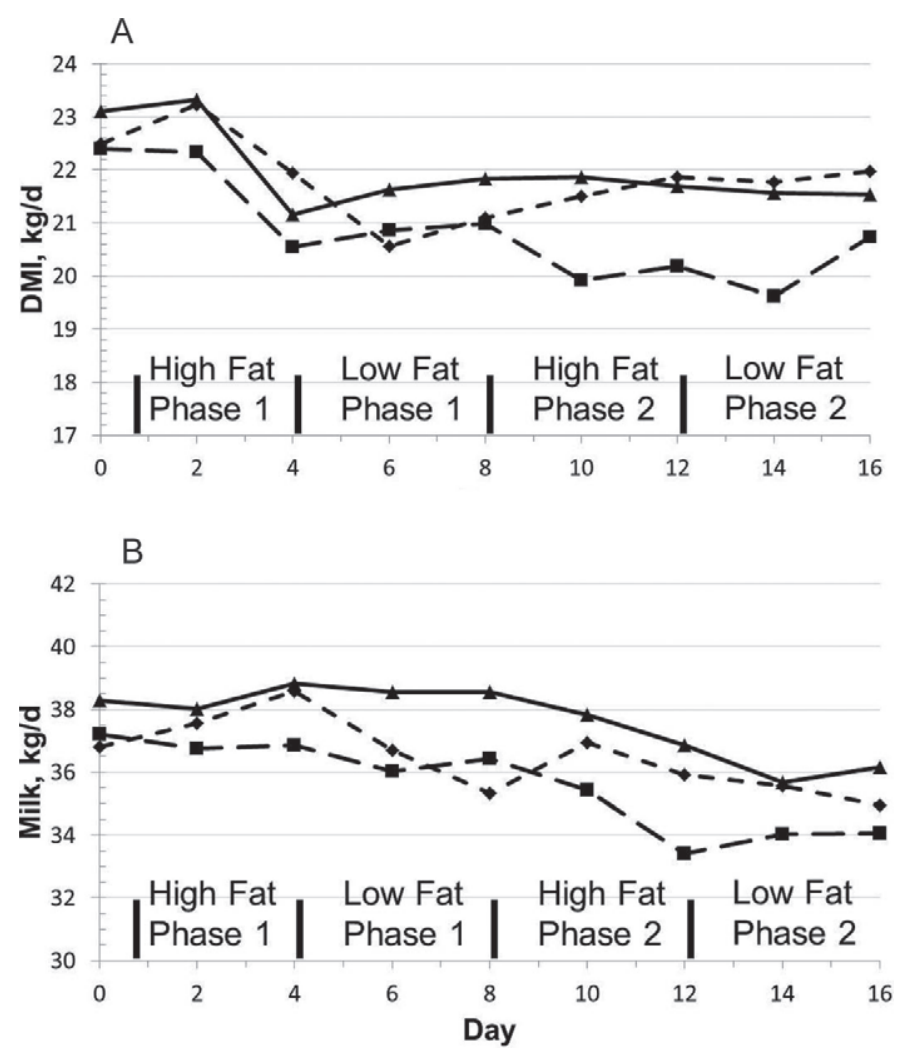

Figure 2. Change in DMI (A) and milk yield (B) over time. The control treatment (short dashed line) consisted of a diet with $5.9 \%$ long-chain FA (LCFA) fed for $16 \mathrm{~d}$. The moderate variation treatment (solid line) consisted of a $6.4 \%$ LCFA diet fed during high-fat phases and a $5.4 \%$ LCFA diet fed during low-fat phases. The high variation treatment (long dashed line) consisted of a diet with 7.0 or $4.8 \%$ LCFA fed during the high- and low-fat phases. Each phase lasted $4 \mathrm{~d}$. A cycle $\times$ treatment interaction was observed for DMI $(P<0.05)$ and milk yield $(P<0.08)$. would be expected based on the concentration of dietary starch, CP, and estimated RDP and RUP (Davidson et al., 2003). Concentrations of MUN had a cyclic pattern, with high values during periods when higher concentrations of fat were fed and lower concentrations during periods when low-fat diets were fed. During the periods with high and low dietary fat, average MUN values for the control treatment were 15.9 and $16.3 \mathrm{mg} / \mathrm{dL}$ (for the control, dietary fat was constant); 16.7 and 16.1 for the moderate variation treatment; and 17.1 and $15.4 \mathrm{mg} / \mathrm{dL}$ for the high variation treatment. When fat was added to the diet, it replaced carbohydrate (approximately half the NDF and NFC), and reducing fermentable carbohydrate can increase MUN, which could account for some of the cyclicity. However, the source of CP also changed when fat concentrations changed (Table 1), with higher fat diets containing more corn gluten meal, regular distillers grains, and urea and less high-protein distillers grains than lower fat diets. Although MUN reflected transient changes in the diet, no overall cumulative effect of variation was observed.

Milk fat percentage was low for all treatments, was not affected by treatment (Table 3) or a treatment $\times$ cycle interaction, and had no consistent cyclical pattern (Figure 3). All diets contained $20.5 \%$ forage NDF, approximately $30 \% \mathrm{NDF}, 40.5 \% \mathrm{NFC}$, and $27 \%$ starch. On the basis of NRC (2001) recommendations, the diets had an acceptable balance of carbohydrates. However, diets were high in unsaturated FA, which can lead to milk fat depression when fed in combination with diets that are high in starch and low in NDF (Griinari et al., 1998). Previously, diets with distillers grains or corn oil with a similar concentration of LCFA as the average concentration of LCFA in this experiment also decreased milk fat concentration but to a much smaller degree (approximately 3.9\% for a diet with saturated fat vs. $3.5 \%$ for diets with distillers grains or corn oil; Abdelqader et al., 2009). The diets in that study had higher concentrations of forage NDF $(22.7 \%)$ and total 
Table 4. Effect of changing dietary fat concentration on milk FA profile ( $\mathrm{g}$ of FA/100 g of total FA)

\begin{tabular}{lcccc}
\hline & Control & $\begin{array}{c}\text { Moderate } \\
\text { variation }\end{array}$ & $\begin{array}{c}\text { High } \\
\text { variation }\end{array}$ & SEM \\
\hline $4: 0$ & 3.30 & 3.43 & 3.34 & 0.17 \\
$6: 0$ & 1.93 & 1.98 & 1.88 & 0.11 \\
$8: 0$ & 0.90 & 0.93 & 0.86 & 0.05 \\
$10: 0$ & 1.93 & 1.96 & 1.85 & 0.11 \\
$12: 0$ & 2.48 & 2.49 & 2.38 & 0.10 \\
$14: 0$ & 9.58 & 9.69 & 9.37 & 0.23 \\
$14: 1$ & 1.33 & 1.27 & 1.18 & 0.10 \\
$15: 0$ & 1.03 & 1.01 & 0.97 & 0.05 \\
$16: 0$ & 24.8 & 24.9 & 25.0 & 0.60 \\
$16: 1$ & 2.14 & 2.01 & 2.01 & 0.13 \\
$18: 0$ & 10.1 & 10.2 & 10.3 & 0.32 \\
$18: 1$ trans-6,8 & 0.98 & 0.90 & 0.95 & 0.06 \\
$18: 1$ trans- 9 & 0.57 & 0.56 & 0.63 & 0.03 \\
$18: 1$ trans-10 & 4.24 & 4.02 & 4.37 & 0.37 \\
$18: 1$ trans-11 & 1.19 & 1.41 & 1.38 & 0.12 \\
$18: 1$ trans- 12 & 0.67 & 0.67 & 0.68 & 0.03 \\
$18: 1$ cis- 9 & 24.9 & 24.5 & 25.2 & 0.60 \\
$18: 1$ cis-11 & 1.09 & 1.04 & 1.04 & 0.05 \\
$18: 2$ & 5.62 & 5.61 & 5.70 & 0.18 \\
$18: 2$ cis- 9, trans-11 & 0.65 & 0.74 & 0.70 & 0.05 \\
$18: 2$ trans-10, cis- 12 & $0.036^{\mathrm{b}}$ & $0.042^{\mathrm{ab}}$ & $0.047^{\mathrm{a}}$ & 0.003 \\
$18: 3$ & 0.38 & 0.38 & 0.37 & 0.01 \\
SCFA & 21.4 & 21.7 & 20.9 & 0.61 \\
LCFA & 50.5 & 50.3 & 51.2 & 0.80 \\
\hline
\end{tabular}

a,b Means within a row differ $(P<0.05)$.

${ }^{1}$ Number of carbons:number of double bonds. SCFA $=$ short-chain FA $(<16 \mathrm{C}) ;$ LCFA $=$ long-chain FA $(>16$ C).

NDF (34\%) than in our study. Generally, experiments designed to evaluate the effect of unsaturated FA use diets that vary in the concentration of unsaturated FA while keeping LCFA constant. In this experiment, the concentrations of total LCFA and unsaturated FA varied across phases (unsaturated FA ranged between 72 and $75 \%$ of dietary LCFA). Harvatine and Allen (2006) reported that milk fat percentage decreased between 0.2 and 0.5 percentage units as dietary unsaturated LCFA increased from approximately 3.9 to $4.9 \%$ of dietary DM (total LCFA was approximately $8 \%$ ). The concentration of unsaturated FA in the high variation treatment changed by 2 percentage units (3.3 and $5.3 \%$ of dietary DM; saturated LCFA increased by 0.3 percentage units), but this did not cause any short (within-cycle) or long-term (16-d) effects on milk fat. The lack of any cyclic or overall effect on milk fat percentage may have been because the average dietary concentration of unsaturated FA was too high and increasing it more had no additional negative effect or the increase in total LCFA counteracted the effect of increased unsaturated FA. Depending on fat source and primary forage use, increasing dietary saturated LCFA can increase milk fat percentage (Onetti and Grummer, 2004), but because the change in saturated LCFA was small, the change in dietary saturated LCFA probably was not adequate to negate the effect of the unsaturated $\mathrm{LCFA}$.
Although milk fat percentage was not affected by treatment and had no cyclic pattern, numerous milk FA had a cyclic pattern. However, only 1 milk FA, trans-10, cis-12 C18:2, was affected by treatments over the entire experiment (Table 4). No interactions were observed between cycle and treatment. Either treatment had no effect during both cycles (most FA) or treatment consistently affected the FA over both cycles

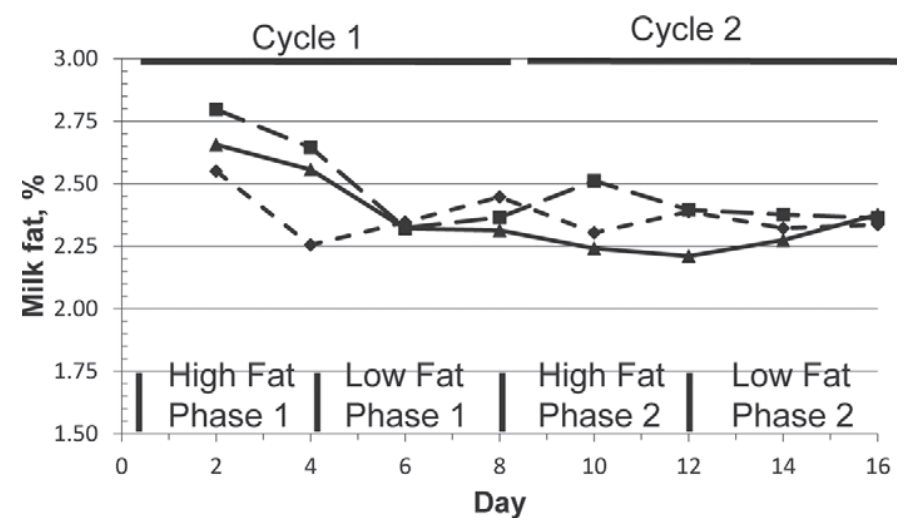

Figure 3. Change in milk fat percentage over time. The control treatment (short dashed line) consisted of a diet with $5.9 \%$ long-chain FA (LCFA) fed for $16 \mathrm{~d}$. The moderate variation treatment (solid line) consisted of a $6.4 \%$ LCFA diet fed during high-fat phases and a $5.4 \%$ LCFA diet fed during low-fat phases. The high variation treatment (long dashed line) consisted of a diet with 7.0 or $4.8 \%$ LCFA fed during the high- and low-fat phases. Each phase lasted $4 \mathrm{~d}$. 

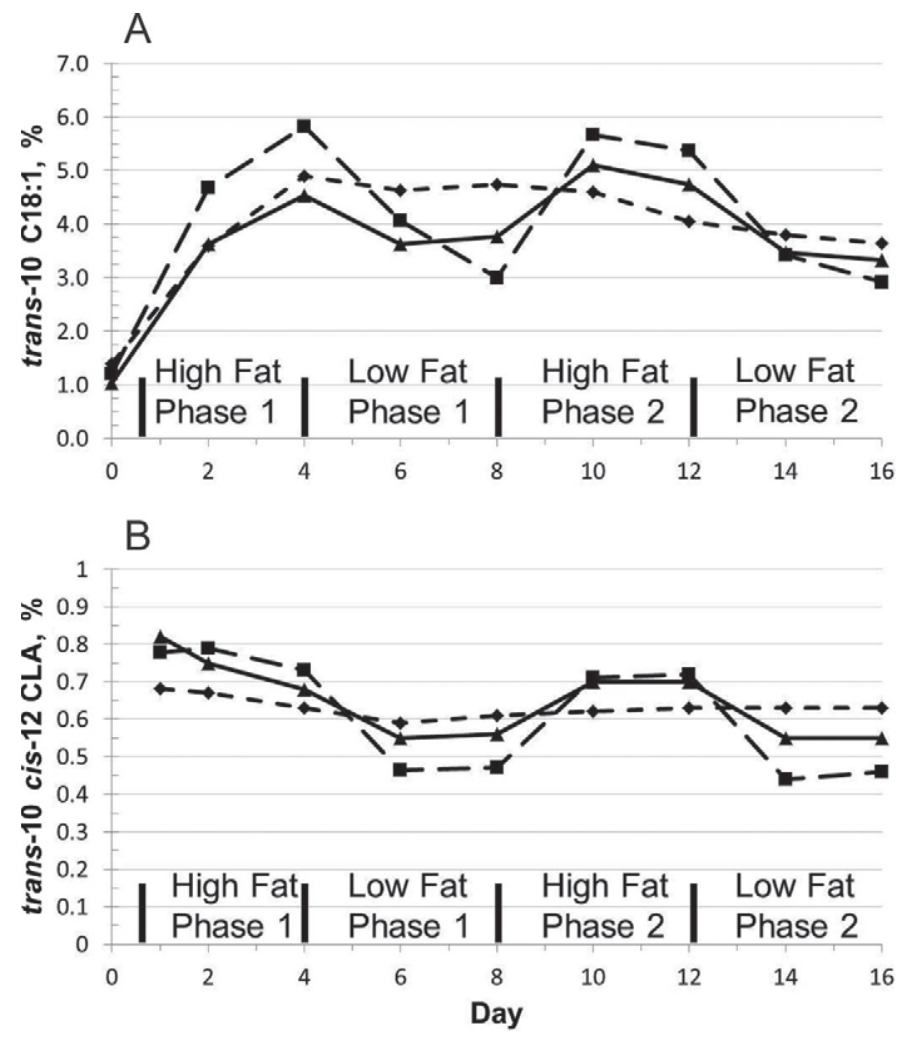

Figure 4. Change in concentrations [\% of total long-chain FA (LCFA)] of trans-10 C18:2 (A) and trans-10, cis-12 conjugated linoleic acid (CLA; B) in milk fat over time. The control treatment (short dashed line) consisted of a diet with 5.9\% LCFA fed for $16 \mathrm{~d}$. The moderate variation treatment (solid line) consisted of a $6.4 \%$ LCFA diet fed during high-fat phases and a 5.4\% LCFA diet fed during lowfat phases. The high variation treatment (long dashed line) consisted of a diet with 7.0 or $4.8 \%$ LCFA fed during the high- and low-fat phases. Each phase lasted $4 \mathrm{~d}$.

(trans-10, cis-12 C18:2). Concentrations of trans-10 C18:1 and trans-10, cis-12 C18:2 had a very clear cyclic pattern (Figure 4). For the high variation treatment, milk trans-10 C18:1 varied from approximately $3 \%$ of total milk FA during the low-fat feeding phases to approximately $6 \%$ during the high-fat feeding phases. The concentration of trans-10, cis-12 C18:2 in milk fat from cows on the high variation treatment had a similar 2 -fold change (approximately 0.03 to $0.065 \%$ ) between the low- and high-fat phases. Changes for those 2 FA followed the same pattern for the moderate variation treatment, but the difference between the fat feeding phases was proportionally less (Figure 4). The pattern for those 2 LCFA mimics the pattern for intake of their precursor, C18:2 (Figure 5). The diets were marginally low in K (Table 2), and Jenkins et al. (2011) found that supplemental $\mathrm{K}$ from $\mathrm{K}$ carbonate (but not $\mathrm{KCl}$ ) reduced the concentrations of both trans-10 C18:1 and trans-10, cis-12 C18:2 in an in vitro rumen system.
The average concentration of trans-10 C18:2 in milk fat was high for all treatments, but was approximately in the middle of the range of reported concentrations when diets with high concentrations of C18:2 were fed (summarized by Cruz-Hernandez et al., 2007). The lack of a treatment effect on trans-10 C18:1 suggests that high concentrations of dietary unsaturated LCFA (5.3\% for the high variation treatment) in bouts of $4 \mathrm{~d}$ followed by 4 -d bouts of lower concentrations of unsaturated LCFA (3.3\%) did not have any carryover effects. The concentration of trans-10 C18:1 started to decrease almost immediately after dietary fat decreased, and it increased almost immediately after dietary fat increased. The length of the phases (i.e., 4 d) may have influenced the apparent lack of any effect. In a previous experiment (Shingfield et al., 2006), cows fed $3 \%$ sunflower oil plus $1.5 \%$ fish oil had severe milk fat depression $(4.6 \%$ for the control vs. $2.9 \%$ for the oil-containing diet), and the milk from the treatment cows had very high ( $7.2 \%$ of milk FA) concentration of trans-10 C18:1. In that experiment, milk fat percentage and trans-10 C18:1 concentration did not reach their nadir or apex, respectively, until the cows were fed the diets for approximately $15 \mathrm{~d}$. In that study, the concentration of trans-10 C18:1 after $4 \mathrm{~d}$ on the experimental diet was approximately doubled compared with d 0 , but it was only approximately $20 \%$ of the maximum concentration observed on d 15. In another study, when cows changed from a diet with extruded soybeans (approximately $20 \%$ LCFA) to a diet with expeller soybean meal (approximately 7\% LCFA) in 3-wk periods, the average concentration of trans-10 C18:1 in milk did not appear to be affected by the diet change (Peterson et

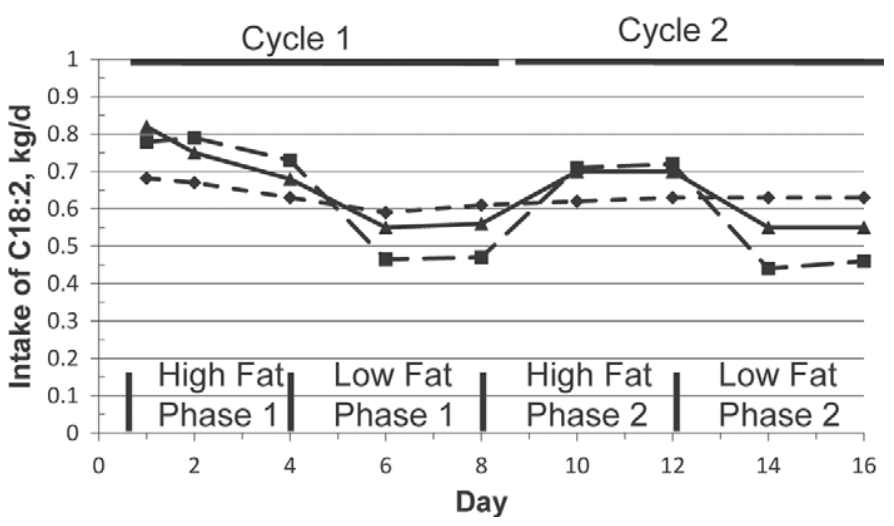

Figure 5. Change in intake of C18:2 over time. The control treatment (short dashed line) consisted of a diet with $5.9 \%$ long-chain FA (LCFA) fed for $16 \mathrm{~d}$. The moderate variation treatment (solid line) consisted of a $6.4 \%$ LCFA diet fed during high-fat phases and a $5.4 \%$ LCFA diet fed during low-fat phases. The high variation treatment (long dashed line) consisted of a diet with 7.0 or $4.8 \%$ LCFA fed during the high- and low-fat phases. Each phase lasted $4 \mathrm{~d}$. 
al., 2002). In that study, concentrations of the trans-10 isomer were low (approximately 0.9\%).

The average concentration of trans-10, cis-12 C18:2 increased with increasing dietary variation in LCFA (Table 4). Although no cycle $\times$ treatment interaction was observed $(P>0.29)$, most of the treatment effect appears to have been caused by the initial change to the very high fat diet in the high variation treatment (Figure 4). A repeated phase of the high-fat diet did not increase the concentration of trans-10, cis-12 C18:2 in milk fat above that observed in the initial phase. In both phases, concentrations of trans-10, cis-12 C18:2 were highest in the composite of milk samples taken 22 and $34 \mathrm{~h}$ after diet change, and they were markedly lower in the composite of the 70- and 82-h post diet change milk samples (cows were still fed the highfat diet at this time). This suggests a rapid change in rumen fermentation (or microbial population) and a rapid compensation to the diet change. In contrast, Shingfield et al. (2006) reported a continual increase in concentration of trans-10, cis-12 C18:2 over at least a 16-d period after a change from a low-fat diet to a diet with sunflower oil and fish oil. In that study, the concentration of cis-9, trans-11 C18:2 peaked at approximately $5 \mathrm{~d}$ after the diet change and then decreased (but never returned to baseline over the 28-d period).

\section{CONCLUSIONS}

All treatments in this experiment resulted in milk with low-fat concentrations, which could affect results. Other than transient changes in milk FA that reflected dietary LCFA, the moderate variation treatment had no effect on production measures. Relative to the high variation treatment, the moderate variation treatment was appropriately named; however, an abrupt change in dietary LCFA by 1 percentage unit (most of this was unsaturated LCFA) is actually quite substantial. The high variation treatment (range of 2 percentage units) had a cumulative negative effect on DMI and milk yield and increased the concentration of trans-10, cis-12 C18:2 in milk, suggesting an altered rumen microbial population.

\section{ACKNOWLEDGMENTS}

This project was supported by National Research Initiative Competitive Grant number 2009-55206-05242 from the USDA National Institute of Food and Agriculture (Washington, DC).

\section{REFERENCES}

Abdelqader, M. M., A. R. Hippen, K. F. Kalscheur, D. J. Schingoethe, and A. D. Garcia. 2009. Isolipidic additions of fat from corn germ, corn distillers grains, or corn oil in dairy cow diets. J. Dairy Sci. 92:5523-5533.

AOAC International. 2000. Official Methods of Analysis of AOAC International. Vol. 1 and 2. 17th ed. AOAC Int., Gaithersburg, MD.

Belyea, R. L., B. J. Steevens, R. J. Restrepo, and A. P. Clubb. 1989. Variation in composition of by-product feeds. J. Dairy Sci. 72:2339-2345.

Buckner, C. D., M. F. Wilken, J. R. Benton, S. J. Vanness, V. R. Bremer, T. J. Klopfenstein, P. J. Kononoff, and G. E. Erickson. 2011. Nutrient variability for distillers grains plus solubles and dry matter determination of ethanol by-products. Prof. Anim. Sci. 27:57-64.

Cole, N. A. 1999. Nitrogen retention by lambs fed oscillating dietary protein concentrations. J. Anim. Sci. 77:215-222.

Cole, N. A., L. W. Greene, F. T. McCollum, T. Montgomery, and K. McBride. 2003. Influence of oscillating dietary crude protein concentration on performance, acid-base balance, and nitrogen excretion of steers. J. Anim. Sci. 81:2660-2668.

Cruz-Hernandez, C., E. K. Okine, L. A. Goonewardene, R. J. Weselake, B. M. Sorensen, J. K. G. Kramer, J. J. Kennelly, and D. R. Glimm. 2007. Evaluating the conjugated linoleic acid and trans 18:1 isomers in milk fat of dairy cows fed increasing amounts of sunflower oil and a constant level of fish oil. J. Dairy Sci. 90:3786-3801.

Dairy One. 2011. Feed Composition Data Base. Dairy One, Ithaca, NY. Accessed Mar. 10, 2011. http://www.dairyone.com/Forage/ FeedComp/MainLibrary.asp.

Davidson, S., B. A. Hopkins, D. E. Diaz, S. M. Bolt, C. Brownie, V. Fellner, and L. W. Whitlow. 2003. Effects of amounts and degradability of dietary protein on lactation, nitrogen utilization, and excretion in early lactation Holstein cows. J. Dairy Sci. 86:16811689.

DePeters, E. J., J. G. Fadel, M. J. Arana, N. Ohanesian, M. A. Etchebarne, C. A. Hamilton, R. G. Hinders, M. D. Maloney, C. A. Old, T. J. Riordan, H. Perez-Monti, and J. W. Pareas. 2000. Variability in the chemical composition of seventeen selected byproduct feedstuffs used by the California dairy industry. Prof. Anim. Sci. 16:69-99.

Griinari, J. M., D. A. Dwyer, M. A. McGuire, D. E. Bauman, D. L. Palmquist, and K. V. V. Nurmela. 1998. trans-Octadecenoic acids and milk fat depression in lactating dairy cows. J. Dairy Sci. $81: 1251-1261$.

Harvatine, K. J., and M. S. Allen. 2006. Effects of fatty acid supplements on milk yield and energy balance of lactating dairy cows. J. Dairy Sci. 89:1081-1091.

Jenkins, T. C. 2000. Feeding oleamide to lactating Jersey cows 1. Effects on lactation performance and milk fatty acid composition. J. Dairy Sci. 83:332-337.

Jenkins, T. C., E. Block, and P. H. Morris. 2011. Potassium reduces the accumulation of trans-10, cis-12 conjugated linoleic acid and trans-18:1 in continuous cultures of mixed ruminal microorganisms regardless of dietary fat level. J. Dairy Sci. 94(E-Suppl. 1):509. (Abstr.)

Ludden, P. A., T. L. Wechter, and B. W. Hess. 2002. Effects of oscillating dietary protein on nutrient digestibility, nitrogen metabolism, and gastrointestinal organ mass in sheep. J. Anim. Sci. 80:3021-3026.

NRC. 2001. Nutrient Requirements of Dairy Cattle. 7th rev. ed. Natl. Acad. Press, Washington DC.

Onetti, S. G., and R. R. Grummer. 2004. Response of lactating cows to three supplemental fat sources as affected by forage in the diet and stage of lactation: A meta-analysis of literature. Anim. Feed Sci. Technol. 115:65-82.

Peterson, D. G., J. A. Kelsey, and D. E. Bauman. 2002. Analysis of variation in cis-9, trans-11 conjugated linoleic acid (CLA) in milk fat of dairy cows. J. Dairy Sci. 85:2164-2172.

SAS Institute. 2009. SAS/STAT ${ }^{\circledast} 9.2$ User's Guide. 2nd ed. SAS Inst. Inc., Cary, NC.

Shingfield, K. J., C. K. Reynolds, G. Hervas, J. M. Griinari, A. S. Grandison, and D. E. Beever. 2006. Examination of the persis- 
tency of milk fatty acid composition responses to fish oil and sunflower oil in the diet of dairy cows. J. Dairy Sci. 89:714-732.

Spiehs, M. J., M. H. Whitney, and G. C. Shurson. 2002. Nutrient database for distillers dried grains with solubles produced from new ethanol plants in Minnesota and South Dakota. J. Anim. Sci. 80:2639-2645.

University of Minnesota. 2009. Distiller grains byproducts in livestock and poultry feeds. Accessed Mar. 17, 2010. http://www.ddgs.umn. edu/profiles-archived-us/us_profile_comparison_march_2009.pdf.

Weiss, W. P., D. Shoemaker, L. R. McBeth, P. Yoder, and N. R. St-Pierre. 2012. Within-farm variation in nutrient composition of feeds. Pages 103-140 in Proc. Tri-State Dairy Nutr. Conf., Ft. Wayne, IN. Ohio State Univ., Columbus.

Weiss, W. P., and D. J. Wyatt. 2000. Effect of oil content and kernel processing of corn silage on digestibility and milk production by dairy cows. J. Dairy Sci. 83:351-358.

Weiss, W. P., and D. J. Wyatt. 2003. Effect of dietary fat and vitamin $\mathrm{E}$ on $\alpha$-tocopherol in milk from dairy cows. J. Dairy Sci. $86: 3582-3591$. 